he had a few convulsions but no impaired consciousness or other signs of severe malaria. On day 2 the parasitaemia was $4 \%$. Treatment was changed to mefloquine, which was successful. His 4 year old brother, case 2 , was febrile with $0.5 \%$ infected erythrocytes. His symptoms resolved with atovaquone and proguanil hydrochloride, and the parasites were cleared after three days. On day 28 he was again febrile with $P$ falciparum parasites and was successfully treated with mefloquine. The mother (case 3), although asymptomatic, had a few $P$ falciparum rings. She was treated with atovaquone and proguanil hydrochloride, which cleared the parasites without recrudescence.

Drug concentrations were measured by high pressure liquid chromatography in repeated serum samples. The concentrations of atovaquone (7.6-13.9 $\mu \mathrm{M})$, proguanil (300-1200 $\mathrm{nM})$, and cycloguanil (125-400 nM) were all above the levels considered therapeutic in children and adults. ${ }^{3}$ Treatment failure could therefore not be attributed to poor bioavailability of the drug.

Cases 1 and 3 were infected with single clones whereas case 2 had five genetically diverse parasite populations, detected by analysis of merozoite surface proteins 1 and 2. Mutation A803G (changing tyrosine to serine in 268) in cytochrome b, related to resistance to atovaquone, was detected in cases 2 and 3 by polymerase chain reaction and restriction fragment length polymorphism of loci 133, 268, 272, 275, 280, and 284, and confirmed by sequencing (table). ${ }^{4}$ However, only wild types were found in case 1 . Analyses of loci 51, 59, 108, and 164 in the dihydrofolate reductase gene, related to resistance to proguanil and cycloguanil, revealed wild types in all samples except those from case 2 , in which triple mutation were found at recrudescence. ${ }^{5}$

\section{Comment}

Treatment of three patients with atovaquone and proguanil hydrochloride for $P$ falciparum malaria was unsuccessful in two non-immune children but successful in an adult with probable partial protective immunity. The patients had adequate blood concentrations of the drugs, indicating resistance by $P$ falciparum. Mutation in cytochrome b may have contributed to treatment failure but cannot be the only mechanism for resistance to the drug combination because it was also detected in the patient who responded well and was not detected in the patient with early treatment failure. Atovaquone and proguanil hydrochloride represents one of the main new developments in malaria chemotherapy, but because of the resistance shown at this early stage there is a need for careful surveillance of drug efficacy.

Contributors: JL treated the patients. AF coordinated the analyses and wrote the paper with the assistance of the other authors, specifically AB. NL, YB, and MT performed the pharmacological analyses. PG, GS, and SB performed the genetic analyses. AF will act as guarantor for the paper.

Funding: None.

Competing interests: JL has been reimbursed by GlaxoSmith Kline for speaking at a meeting.

1 Looareesuwan S, Chulay JD, Canfield CJ, Hutchinson DB. Malarone (atovaquone and proguanil hydrochloride): a review of its clinical development for treatment of malaria. Am J Trop Med Hyg 1999;60:533-41.

2 Fivelman QL, Butcher GA, Adagu IS, Warhurst DC, Pasvol G. Malarone treatment failure and in vitro confirmation of resistance of Plasmodium falciparum isolates from Lagos, Nigeria. Malaria J 2002;1:1.

3 Sabchareon A, Attanath P, Phanuaksook P, Chanthavanich P, Poonpanich $\mathrm{Y}$, Mookmanee D, et al. Efficacy and pharmacokinetics of atovaquone and proguanil in childen with

4 Korsinczky M, Chen N, Kotecka B, Saul A, Rieckmann K, Cheng Q. Mutations in Plasmodium falciparum cytochrome $\mathrm{b}$ that are associated with atovaquone resistance are located at a putative drug-binding site. Antimicrob Agents Chemother 2000;44:2100-8.

5 Sirawaraporn W, Sathitkul T, Sirawaraporn R, Yuthavong Y, Santi DV. Antifolate-resistant mutants of Plasmodium falciparum dihydrofolate reductase. Proc Natl Acad Sci USA 1997;94:1124-9.

(Accepted 9 January 2003)

\title{
Media criticism of doctors: review of UK junior doctors' concerns raised in surveys
}

\author{
Michael J Goldacre, Julie Evans, Trevor W Lambert
}

We conduct regular surveys of junior doctors' career intentions and views on their training and work. ${ }^{12}$ At the end of the structured questionnaire we invite respondents to add comments on any aspect of their career choice, training, or work. The great majority of the comments we receive relate to topics raised by us, although some respondents raise other topics. In the replies to questionnaires sent to doctors who qualified in 1999 and 2000, a new theme (not raised by us) emerged among the comments: critical portrayal of doctors in the news media. We report on these comments here.

\section{Method and results}

We sent questionnaires to all doctors who qualified from any UK medical school in 1993, 1996, 1999, and 2000; we did this towards the end of their preregistration year. In all, 5547 (74\%) of the 7466 qualifiers of 1993 and 1996 replied, as did 5702 (67\%) of the 8494 qualifiers of
1999 and 2000. Forty per cent (2194) of the respondents of 1993 and 1996 added written comments on their questionnaires, as did 39\% (2217) of those of 1999 and 2000. Comments were keyed and imported into software designed for coding and searching text. ${ }^{3}$ After reading the doctors' comments, we decided to search systematically for all comments that included the text strings "media," "press," "news," "newspapers," "doctor bashing," and "doctor-bashing." We read all comments extracted by this search and eliminated any that used the word(s) in a different context from concerns about the portrayal of doctors in the news media.

This yielded comments from three respondents from the combined 1993 and 1996 cohorts and 63 from the combined 1999 and 2000 cohorts. The box shows some of these comments (verbatim)-chosen to represent the main issues raised and to illustrate the wide geographical spread of those who raised them. They tended to make their comments about the media
UK Medical Careers Research Group, Unit of Health-Care Epidemiology, Department of Public Health, University of Oxford, Institute of Health Sciences, Oxford OX3 7LF Michael J Goldacre director

Julie Evans social scientist Trevor W Lambert statistician

Correspondence to: MJ Goldacre michael.goldacre@ dphpc.ox.ac.uk

BMJ 2003;326:629-30 
Respondents' comments about portrayal of doctors in news media*

- Media attitudes and seemingly constant negative criticism are having a significant effect on morale of doctors around me (Northern and Yorkshire)

- Getting a bit disillusioned with constant negative press coverage

(South East)

- The media are always portraying doctors in a poor light and constantly

"doctor bashing" (North West)

- Doctor bashing constantly in the media (London)

- It's particularly difficult now that doctors are being witch-hunted by the UK press (North Western)

- Staff on the whole are fed up with being slated in the press (South West)

- Constantly under attack by the media (Scotland)

- I feel strongly that as a profession we need to start fighting for our reputation in the media-without trust our job will be unbearable, impossible, stressful, and unenjoyable (Trent)

- I often feel very guilty being a doctor, or sometimes ashamed, as we have such a bad press (Wales)

- The media demonises the medical profession-seizing upon the occasional failure (of course these must be addressed) to condemn the entire profession (London)

- Deteriorating attitude of general public, media, government to role of doctor (South East)

- Government is currently battering public support for doctors by promoting "dodgy doctor" scandals (Scotland)

- Seemingly unquenchable thirst for medical blood in the press-doctor bashing does just that, damages doctors! (London)

- Media opinion of the medical profession ("blundering doctors") has spilled over on to the wards, and patients question everything we do (South East)

- Respect has gone, media medic bashing has done its job (London)

- In view of the current media and government enthusiasm for portraying doctors in such a negative light, I feel let down that no influential body, BMA etc, is attempting to defend the majority of doctors who work hard and competently in a difficult, stressful environment (Northern and Yorkshire)

- Considering working abroad because of current "doctor bashing" in the media (Trent)

- I would consider leaving medicine if current anti-doctor media worsens (South East)

- If morale/conditions and public/political/media attitudes remain the same then may seriously consider leaving medicine (London)

- I am happy with my choice of job but it does not surprise me to hear of people who wish to leave medicine, especially now when the media highlights to the public the mistakes made by a small minority in the medical profession (Northern Ireland)

- I will stay in medicine, despite all the doctor bashing in the press, I am still proud to be part of the profession (South East)

*NHS region or country of doctor's medical school is in parentheses

alongside comments about broader aspects of their work. Typical comments showed that these respondents felt demoralised or undermined by criticism of doctors in the media. A few commented that such criticism was making them doubt whether they wished to continue in medicine, and a few emphasised that they would not be put off medicine by criticism in the media.

\section{Comment}

Doctors who have qualified recently have begun to comment that they are being demoralised by the news media's criticism of the profession. Only a small minority of respondents to our surveys comment on any topic that we do not raise with them. It is hard to know whether views like those in the box would have proved to be widely held by doctors if we had asked respondents specifically about media coverage. We were struck, however, by the similarity of expression about portrayal in the news media from doctors writing from different geographical locations. We were also struck by their strength of feeling. Although the numbers were small, it would be a pity if these sentiments were becoming common among young doctors right at the start of their careers. Moreover, if school students considering a medical career are similarly affected by adverse media comment, some may change their minds. On the one hand, professions cannot expect to avoid criticism: no doubt all professions sometimes feel vilified by the press. On the other hand, it is clear that criticism considered to be unfair has a real, damaging effect on the morale of some doctors.

Karen Hollick administered the survey, and Janet Justice and Alison Stockford entered the data. We thank all the doctors who took part in the study.

Contributors: TWL and MJG designed the surveys. MJG and JE analysed the data. MJG wrote the first draft of the paper. All authors contributed to subsequent drafts and are guarantors for the paper.

Funding: The UK Medical Careers Research Group is funded by the Department of Health. The Unit of Health-Care Epidemiology is funded by the South East regional office of the NHS Executive. The guarantors accept full responsibility for the conduct of the study, had access to the data, and controlled the decision to publish.

Competing interests: None declared.

1 Lambert TW, Goldacre MJ, Edwards C, Parkhouse J. Career preferences of doctors who qualified in the United Kingdom in 1993 compared with those of doctors qualifying in 1974, 1977, 1980, and 1983. BMJ 1996 313:19-24.

2 Goldacre MJ, Davidson JM, Lambert TW. Career choices at the end of the pre-registration year of doctors who qualified in the United Kingdom in 1996. Med Educ 1999;33:882-9.

N5 (non-numerical unstructured data indexing searching $\mathcal{E}$ theorizing) qualitative data analysis program. Version 5.0. Melbourne, Australia: OSR International, 2000.

(Accepted 4 February 2003)

\section{Submitting articles to the $B M J$}

We are now inviting all authors who want to submit a paper to the $B M J$ to do so via the web (http://submit.bmj.com).

Benchpress is a website where authors deposit their manuscripts and editors go to read them and record their decisions. Reviewers' details are also held on the system, and when asked to review a paper reviewers will be invited to access the site to see the relevant paper. The system is secure, protected by passwords, so that authors see only their own papers and reviewers see only those they are meant to.

Anyone with an internet connection and a web browser can use the system.
The system provides all our guidance and forms and allows authors to suggest reviewers for their paper. Authors get an immediate acknowledgement that their submission has been received, and they can watch the progress of their manuscript. The record of their submission, including editors' and reviewers' reports, remains on the system for future reference.

The system itself offers extensive help, and the BMJ's editorial office will help authors and reviewers if they get stuck.

Benchpress is accessed via http://submit.bmj.com or via a link from bmj.com 